\title{
The Internationalization of Money and Finance and the Globalization of Financial Markets
}

James R. Lothian

Fordham University, lothian@fordham.edu

Follow this and additional works at: https://fordham.bepress.com/crif_working_papers

Part of the Finance and Financial Management Commons

\section{Recommended Citation}

Lothian, James R., "The Internationalization of Money and Finance and the Globalization of Financial Markets" (2002). CRIF Working Paper series. 12.

https://fordham.bepress.com/crif_working_papers/12

This Article is brought to you for free and open access by the Frank J. Petrilli Center for Research in International Finance at DigitalResearch@Fordham. It has been accepted for inclusion in CRIF Working Paper series by an authorized administrator of DigitalResearch@Fordham. For more information, please contact considine@fordham.edu. 


\title{
The Internationalization of Money and Finance and the Globalization of Financial Markets
}

\author{
James R. Lothian*
}

Distinguished Professor of Finance

Schools of Business

Fordham University

June 2002

Journal of International Money and Finance, 2002 forthcoming.

A revised version of a paper presented at a conference sponsored by the

Journal of International Money and Finance and the

University of Rome Tor Vergata, in Rome, December 5-7, 2001.

\begin{abstract}
In this paper I combine long multi-country time series data for interest rates and stock returns with the institutional evidence for much earlier centuries amassed by economic historians to study the question of financial globalization and how it has altered since the late classical era. At their longest, for Dutch and English short-term interest rates, the quantitative data that I use extend back slightly more than three centuries. The institutional history provides information on an additional millennium's worth of experience. The conclusion that I reach is that the internationalization of money and finance and the globalization of financial markets are not new phenomena. They are part of an evolutionary process that began much earlier and that has continued, albeit with periodic interruptions and reversals, for many centuries. What we see today is simply the latest and most advanced manifestation of this process.

JEL: F30, N20, F33, G15,
\end{abstract}

* Fordham University, Schools of Business, 113 West 60th Street, New York, N.Y. 10023; tel. 212 636-6147; fax 212 765-5573; e-mails, lothian@fordham.edu; jrmlothian@aol.com.. I would like to thank Gerald P. Dwyer, Jr., Michael Melvin and participants at the Tenth Tor Vergata Conference for comments. I have also benefitted from the comments of Jeffrey G. Williamson, and other participants at the ESF Conference on Historical Market Integration held in Venice in December 1999, on a much earlier version of the paper. 
Keywords: Financial inte gration, real interest rates real stock returns, international money, financial history

\section{Introduction}

The focus of this paper is on international financial integration historically. It begins with a review of one of the most fascinating episodes in international monetary history - the introduction by the Emperor Constantine of a new coinage to check inflation that came to be used as an international money and continued to play that role for seven centuries. It goes on to consider the evolution of the foreign exchange and credit markets in the Medieval era and the growth of these markets in the centuries that followed. It concludes with a presentation of statistical evidence on the degree of integration of stock, bond and money markets over the past three centuries.

The implications of both this later quantitative analysis and the earlier historical analysis are complementary. From the end of the seventeenth century, we observe a strong tendency toward international integration in money and bond markets and a similar, but somewhat weaker tendency in that direction in equity markets. This process, however, was both discontinuous and non-monotonic, having been interrupted and in several instances reversed as wars and other dislocations intruded.

The evidence for earlier centuries, although much more fragmentary and much less precise, points to much the same phenomena having taken place. The difference observed between the two periods as well as over time within the two periods centers around the range of financial assets and number of markets involved and the geographical scope of that involvement. Markets today are more complete than earlier; integration is more geographically ubiquitous.

I summarize this evidence in the next two sections of the paper. The first of these discusses the earlier historical evidence; the second summarizes the results of the statistical analysis of the data for interest rates and stock returns. In the fourth and final section of the paper I discuss the substantive conclusions that come out of this work.

\section{Historical Evidence}

We are used to thinking of international financial integration in purely quantitative terms judging 
it on the basis of the law of one price, by measures of portfolio diversification and by the correlation or lack thereof of various components of foreign and domestic income. Since questions of what is big and what is little are notoriously difficult to answer in economics, the all-or-nothing criteria of formal statistical tests have much more often than not has been the basis for such judgements.

Quantitative evidence of this sort is certainly important but such evidence depends on the availability of good numerical data. There is, however, also a wealth of evidence compiled by economic historians extending back very much earlier. This evidence comes from contemporary accounts, business firms' ledgers, notarial records, transcripts of court proceedings and other such documents.

In this section, I discuss the evidence relating to three important episodes: the introduction of the bezant in the fourth century AD and its continued use as an international currency into the second millennium A.D.; the development of a foreign exchange cum credit market - the two were inseparably linked - and of banking in Medieval times; and the beginnings of modern markets in tradable financial instruments in the sevente enth century.

\section{A. International Monies}

Descriptions of banking transactions in Europe date from the ninth century (Lopez, 1979), and it is clear from these descriptions and those of the immediately following centuries that these early banking transactions had a strong international dimension. The Medieval era, however, marked neither the start of international finance per se nor the first period in which the sign s of financial globalization became manifest. For that we have to go back many centuries earlier to the reign of the Emperor Constantine. ${ }^{2}$

In the three centuries that followed the demise of the Roman Republic, currency debasement and inflation were a continual problem. This debasement, however, ended abruptly in the fourth century

${ }^{2}$ For additional discussion of the history of international monies see Dwyer and Lothian (2002) and references cited therein. 
A.D. when the Emperor Constantine introduced a full-bodied, stable gold coinage. ${ }^{3}$ This coin, known variously as the solidus, the bezant and the nomisma, was remarkable both for its stability and its longevity. The bezant kept very nearly the same gold content until the middle of the eleventh century and continued to be coined in Byzantium until the thirteenth. It became a true international currency and was used throughout the Mediterranean region. It was, as one scholar subsequently put it, "the dollar of the Middle Ages." Until the seventh century, when a very nearly identical coin, the dinar, was introduced in the Moslem world, the bezant also had what amounted to a monopoly position.

At the very basic level of monetary transactions globalization clearly took place. Interestingly, in light of developments in Europe today, it was largely a spontaneous process - much more in the spirit of Hayek than of Brussels. Both coins were introduced by governments but such introduction in no way insured their continued use over many centuries. That depended on more than simply government fiat.

\section{B. Banking in the Medieval World}

Information on banking in Europe becomes tolerably good in the eleventh century and by the next century improves further. Genoese notarial records exist starting in the year 1154 and from these records historians have constructed a detailed schematic of banking in the late twelfth century and the early part of the thirteenth (de Roover, 1974, Chapter 5).

The thirteenth century by all accounts was an extraordinary period. It was a time of great learning and of considerable intellectual interchange. ${ }^{4}$ It saw the start of a commercial revolution in which trade increased greatly, both within Europe and between Europe and the rest of the world. It was, moreover, a period of financial innovation in which banking developed further and became truly international and in which a gold coinage returned to Europe (Spufford, 1986). Like the earlier bezant,

3 See Einzig (1970) for a summary of monetary developments during the period of the Roman Empire and Cipolla (1967) for an extensive treatment of the bezant and the other early international monies.

4 A particularly interesting discussion of this period, both from the standpoint of economic thought and of intellectual history more generally is contained in Schumpeter's (1954) chapter on scholastic economic thought. In this regard, see also Gilson ( 1991). 
these new coins achieved the status of world currencies.

International trade during the thirteenth century was centered around the regular fairs that were held in various parts of Europe, most notably those of Champagne and Brie. ${ }^{5}$ These fairs quite naturally also became centers of foreign exchange activity. The foreign exchange traders of the time, the money changers, at first confined themselves to literal exchange transaction in which one type of coin was exchanged for another. Then as bills of exchange increasingly came into use, these money changers, as also certain merchants, branched out to become intermediaries in this process.

A major purpose of these bills of exchanges was to eliminate the need for specie shipments each time that goods were bought and sold internationally. The bill of exchange was an order to pay at some future date the foreign currency equivalent of a given sum of domestic money received today. Because of the time element involved it also, therefore, entailed credit extension, which was an additional and in many instances primary motivation for its use. The bill of ex change evidently was a quite effective device, since it remained an important vehicle for foreign exchange transactions throughout most of the nineteenth century, and indeed survives today in modified form when coupled with a letter of credit. ${ }^{6}$

A typical trade-motivated transaction would work something like this. Sarno, a Genoese merchant, wants to buy cloth from LeBlanc at the fair in Provins. To pay for this transaction and to avoid having to ship specie, Sarno purchases a bill of exchange from Tullio, a local merchant banker, paying in Genoese genoin. Sarno then presents the bill as payment to Le Blanc who turns the cloth over to him and remits the bill to Martino, a merchant banker operating in Provins. Martino pays Le Blanc in Tournois of Provins and then goes on to settle with Tullio, his counterpart in Genoa. This might be simply a bookkeeping transaction, or it could involve an actual specie shipment, perhaps at some time in the future chosen by the two as a date for reconciling their books.

An alternative motivation for the issuance of the bill is borrowing. In the example above, Sarno

5 See Pirenne (1936) and de Roover (1974, Chapter 5) for discussions of these fairs.

${ }^{6}$ Further discussion of bills of exchange and the transactions they entailed can be found in Neal (1990), in the various works of de Roover, such as de Roover (1974, 1963), and in Spufford (1986). 
would play the role of the lender and Tullio the role of the borrower. The interest rate on the loan would of course not be fixed since the exchange rate at which settlement eventually occurred would be the spot rate at the settlement date and, hence, not decided in advance. An analogous instrument today would be a foreign-currency denominated floating rate note. There are indications that in a world in which ordinary borrowing and lending were regarded as usurious circuitous transactions of this sort were often resorted to (Spufford, 1986).

In any event, whether used as a means of payment or to obtain credit, the widespread use of bills of exchange meant that this early banking was by its very nature international in scope. Making it even more so was the way banking came to be organized in late Medieval times, with international branch networks and correspondent relationships becoming the rule.

The principal players in banking at that time were Northem Italian. These Italian bankers were active in the fairs and later established branch networks throughout much of Europe. In the fourteenth and fifteenth centuries, Bologna, Florence, Genoa, Lucca, Milan, Palermo, Pisa, Sienna, Venice, Barcelona, Valencia, Palma de Majorca, Bruges, Avign on, Montpelier, Paris and London had become centers of such activity. Many of these cities had banking offices that were either actual branches of major Northern Italian merchant banking firms banks or had correspondent relationships with them. De Roover (1974, Chapter 5) likens the typical arrangement at that time to modern bank holding companies. Records of financial transactions suggest that then as now arbitrage was a standard banking activity, with transfers of funds from one place to another dependent on the relative returns to those investments. These bankers also took deposits and engaged in transfers of funds among the accounts of customers of their respective banks.

The reintroduction of a Western European gold coinage took place in 1252 with the striking of two full-bodied gold coins in Northern Italy - the genoin of Genoa and then a few months later the fiorina (or florin) of Florence (Lopez, 1956). These came in response to the monetary muddle brought about by debasement that was then engulfing Europe and the Mediterranean basin. As with the earlier bezant, an important additional stimulus was the need for a coin that could be used in international trade. For the next century and a half these two coins, the florin particularly, were the currencies of 
international trade with smaller denomination silver coins and coins of various baser metals used in most internal transactions. In the fifteenth century, however, their place was taken by the ducato of Venice.

During the thirteenth century, data for exchange rates start to become available. ${ }^{7}$ Throughout Europe smaller denomination silver coins and coins of various baser metals were used in most internal transactions. A good overview of exchange-rate behavior, therefore, can be had by examining the rates of exchange between these coins and the gold coins used as the international money. Table 1, Column 3 presents such data, using the Florentine gold florin as the numeraire. Shown in the table are per cent changes of the exchange rates of six silver-based coinages relative to the florin for the period 1252 to 1500. In each instance, the silver-based currency depreciated in value relative to the international currency, the florin. A major factor engendering these movements was the series of debasements that took place in all of the European countries throughout this era. As it happens, estimates of the extent of debasement of these six currencies have also been made (Cipolla, 1963). These are shown in per cent terms in the second column of the table. These differ substantially, the pound sterling showing relatively little movement, a drop in value of only 60 per cent over these two and a half centuries and the Milanese soldi, in contrast, registering a decline of 220 per cent. ${ }^{8}$ The correspondence between the extent of the debasement of the various coinages and the exchange rate depreciation is exceedingly close - a simple correlation coefficient and a rank correlation coefficient of .94 each. The upshot is, that as far back as Medieval times, there was an active market in foreign exchange, which, judging by these comparisons, behaved very much as one would expect.

\section{C. The Development of Markets in Tradable Instruments}

7 Spufford (1986) provides such data for a great number of currencies over the two and a half centuries from 1252 to 1500 .

8 This disparity between the two is also consistent with what is known about monetary behavior over this period. Sterling was relatively free from debasement until the time of Henry VIII (1509-1547); the continental currencies, in contrast, were not. See Chown (1992) and Feaveryear (1963) for discussions of English experience prior to and during the reign of Henry VIII. 
The Champagne fairs diminished greatly in importance during the early fourteenth century and by the end of the fifteenth the private Italian banks had suffered similar fate, their ranks almost totally depleted by failures. Two sets of institutions gradually evolved to fill the void. The first were the public banks, governmentally affiliated banking institutions like the Bank of Amsterdam. The second was the development during the course of the sixteenth century of the principle of negotiability. The public banks were among other things the engines by which discounting of commercial paper and similar financial instruments came into use. Acceptance of the principle of negotiability and the resultant issuance of negotiable instruments were a sine qua non for development of the modern money market. Another sixteenth-century change that gained greater force in the two centuries that followed was a shift in the geographical focus of financial activity from Southern Europe to the fringes of Northern Europe, from Italy to the Low Countries initially, first to Antwerp, next to Bruges, and then to Amsterdam, and finally to England and its center of financial activity, London. ${ }^{9}$

At the end of the seventeenth century, the Dutch Republic was the world's foremost commercial empire and Amsterdam its most important financial center. The latter was a major center of financial trading and Dutch investment activity, a large part of which was directed at England. During these years, Amsterdam and London had close financial links, with Amsterdam the senior partner (Eagly and Smith, 1976; Neal, 1990).

The Dutch of this era were important financial innovators and international arbitrageurs. Perpetual bonds were a Dutch invention, futures contracts, margins, short sales and a number of other financial-market instruments and techniques that today are regarded as modern were commonplace in the Amsterdam of the seventeenth century (Homer and Sylla, 1976).

The Amsterdam Exchange, the center of Dutch financial trading activities, became truly international in its focus during this period. In the early seventeenth century, trading centered almost exclusively around Dutch East India Company shares, a small number of commodities and bills of exchange. By the start of the next century, that had changed. The Amsterdam Exchange became a world

9 See Rousseau and Sylla (2002 forthcoming) for an overview of Dutch and English financial developments during this period 
market in which a wide range of securities and commodities were traded..$^{10}$

England, in contrast, did not begin its development into a financial power until the end of the seventeenth century. Here the chartering of the Bank of England in 1694 is regarded as the event that got the ball rolling. Then, in the century that followed English commercial banking began to develop rapidly. The number of London banks more than tripled between 1750 and 1800; the number of country banks grew even faster, increasing by a factor of close to thirty over that half century, and then doubling again between 1800 and 1810 (Ashton, 1955, pp. 179-183). During this period, the London Stock Exchange also was set up and an active market in foreign exchange begun (Michie, 1987). The end result of all this, and with a strong helping hand from the Napoleonic Wars and the French occupation of the Netherlands, was London's eclipse of Amsterdam as an international financial center.

A major contributing factor to both Dutch and English financial development was the development of a financial press in the two countries that regularly reported financial-market price quotes. The Dutch beurscourant was first on the scene in 1585. By 1613 it was a weekly. By the eighteenth century a thrice-weekly publication the Amsterdamasche Courant was appearing. In it were listed market prices both of securities sold and real estate sold (Dehing and Marjolein 't Hart, 1997, p.54). The best known and longest in operation in England was the twice-weekly Course of the Exchange founded in 1697 by John Castaing, a London broker and Huguenot immigrant, and continuously published for eighty years thereafter (Neal, 1990). By the eighteenth century, moreover, there was a regular communication system functioning between Amsterdam and London for exchanging financial information (Dehing and 't Hart, 1997, p.58).

\section{Empirical Measures of Financial Integration}

The principal measures of financial integration that I use in the empirical comparisons presented below are real-interest-rate equalization and real-stock-return equalization. As a check on the accuracy of the first I use deviations from uncovered interest parity.

In an integrated economy, real rates of return on physical assets will tend to converge as also will

${ }^{10}$ See the accounts in Homer and Sylla (1996) and Dehing and t'Hart (1997). 
real rates of return on financial assets. Real rate equalization is, therefore, the broadest, and for that reason most theoretically appealing of the various measures of financial integration. ${ }^{11}$

Real interest rate equalization typically has been viewed in terms of the following decomposition:

$$
\rho_{\mathrm{t}}-\rho_{\mathrm{t}}^{\mathrm{F}}=\left[\left(\mathrm{R}_{\mathrm{t}}-\mathrm{R}_{\mathrm{t}}^{\mathrm{F}}\right)-\hat{\mathrm{s}}_{\mathrm{t}}^{*}\right]+\left[\hat{\mathrm{s}}_{\mathrm{t}}^{*}-\left(\pi_{\mathrm{t}}^{*}-\pi_{\mathrm{t}}^{* \mathrm{~F}}\right)\right]
$$

where $\rho_{\mathrm{t}}-\rho_{\mathrm{t}}^{\mathrm{F}}$ is the ex ante real interest differential, $\left(\mathrm{R}_{\mathrm{t}}-\mathrm{R}_{\mathrm{t}}^{\mathrm{F}}\right)$ is the nominal return differential, $\hat{\mathrm{s}}_{\mathrm{t}}^{*}$ is the anticipated percentage change in the nominal exchange rate, $\left(\pi_{\mathrm{t}}^{*}-\pi_{\mathrm{t}}^{* \mathrm{~F}}\right)$ is the differential in anticipated inflation rates and the superscript $\mathrm{F}$ denotes the foreign country. ${ }^{12}$

In equation (1) the ex ante real rate differential is, therefore, seen as made up of two components: $\left[\left(\mathrm{R}_{\mathrm{t}}-\mathrm{R}_{\mathrm{t}}^{\mathrm{F}}\right)-\hat{\mathrm{s}}_{\mathrm{t}}^{*}\right]$, the deviation from uncovered interest parity and $\left[\hat{\mathrm{s}}_{\mathrm{t}}^{*}-\left(\pi_{\mathrm{t}}^{*}-\pi_{\mathrm{t}}^{* \mathrm{~F}}\right)\right]$, the deviation from anticipated purchasing power parity in rate of change form. Equality of ex ante real rates requires that either of two conditions be satisfied, that either UIP and PPP both hold perfectly or that deviations from the two conditions completely offset one another. The implication of the first set of conditions is that the law of one price holds perfectly over the time horizon in question in an ex ante sense in both bond markets and goods markets. In the long run, both do in fact appear to hold tolerably well. In the short run, however, both perform poorly. ${ }^{13}$ The second would be true if deviations from UIP and PPP were due

11 See Frankel (1992) for a discussion of alternative criteria for assessing the degree of financial integration and Furstenberg (1998) for a theoretical overview of the literature on the subject. See Bordo (2000), Goldberg, Lothian and Okunev (2001) and Goodwin and Grennes (1993), Jackson and Lothian (1993), Johnson (1992) Lothian (2000) and Obstfeld and Taylor (2002) for various empirical approaches to the questions of financial integration and real-interest equalization.

12 For this equation to hold, rates of inflation and the rate of change of the exchange rate have to be defined in terms of logarithmic derivatives; for discrete data it will only hold as a first approximation.

13 See Lothian and Simaan (1998) for evidence on the performance of these two relationships at various time horizons over the past several decades. 
to a common cause. Errors in agents' forecasts of exchange rates is one that has been mentioned prominently in the recent literature (e.g., Marston, 1994). Under rational expectations, however, such errors will be mean zero. Over long periods, therefore, these errors are likely to be very much smaller than over shorter periods. Arguably, this accounts for the improved performance of UIP and PPP at longer time horizons during the past three decades, a period in which such errors appear at times to have been substantial.

The economic rationale for real interest equalization, however, can also be stated somewhat differently. In the standard Fisherian framework (see in particular, Fisher, 1907, pp. 279-280), the real rate of interest is the real rate of return on physical assets -- in Fisher's terminology the "commodity rate of interest." It and the real rate of interest on financial assets are linked via an arbitrage relationship. Using such a framework in place of equation (1), we can view the cross-country differential in real returns on financial assets as being composed of quite different components than those on the right hand side of equation (1): the differential in real rates of return on physical assets and the (two) within-country differentials between real interest returns on physical assets and on financial assets:

$$
\rho_{\mathrm{t}}-\rho_{\mathrm{t}}^{\mathrm{F}}=\left[\bar{\rho}_{\mathrm{t}}-\bar{\rho}_{\mathrm{t}}^{\mathrm{F}}\right]+\left[\left(\rho_{\mathrm{t}}-\bar{\rho}_{\mathrm{t}}\right)-\left(\rho_{\mathrm{t}}^{\mathrm{F}}-\bar{\rho}_{\mathrm{t}}^{\mathrm{F}}\right)\right]
$$

where a $\bar{\rho}_{\mathrm{t}}$ and $\bar{\rho}_{\mathrm{t}}^{\mathrm{F}}$ are the real returns on the physical assets in the two countries. The first term on the right-hand side reflects the degree of arbitrage across countries; the second, the degree of financial intermediation within the two countries. Friedman and Schwartz (1982, pp. 513-517), using such a Fisherian framework in their analysis of the UK and US, relate the nominal interest rate differential on bonds to the two factors identified above and to the differential in the two countries' inflation rates. Writing their equation in terms of anticipated rather than actual rates of inflation, we get:

$$
\mathrm{R}_{\mathrm{t}}-\mathrm{R}_{\mathrm{t}}^{\mathrm{F}}=\left(\bar{\rho}_{\mathrm{t}}-\bar{\rho}_{\mathrm{t}}^{\mathrm{F}}\right)+\left(\left[\rho_{\mathrm{t}}-\bar{\rho}_{\mathrm{t}}\right]-\left[\rho_{\mathrm{t}}^{\mathrm{F}}-\bar{\rho}_{\mathrm{t}}^{\mathrm{F}}\right]\right)+\left(\pi_{\mathrm{t}}^{*}-\pi_{\mathrm{t}}^{* \mathrm{~F}}\right),
$$

which is simply a transformation of (2). If PPP holds in rate of change form then the last term can be replaced by the percentage change in the exchange rate and (3) can be rewritten as: 


$$
\mathrm{R}_{\mathrm{t}}-\mathrm{R}_{\mathrm{t}}^{\mathrm{F}}-\hat{\mathrm{s}}_{\mathrm{t}}=\left(\bar{\rho}_{\mathrm{t}}-\bar{\rho}_{\mathrm{t}}^{\mathrm{F}}\right)+\left(\left[\rho_{\mathrm{t}}-\bar{\rho}_{\mathrm{t}}\right]-\left[\rho_{\mathrm{t}}^{\mathrm{F}}-\bar{\rho}_{\mathrm{t}}^{\mathrm{F}}\right]\right)
$$

Here the deviation from UIP is the dependent variable.

In the empirical work that follows, I use the current rate of inflation as a proxy for the anticipated rate. In large samples, given rational expectations, errors associated with this measure will tend toward zero. I, therefore, place more confidence in inferences with regard to the long-run behavior of real interest differentials than their short-term movements.

Another reason to emphasize long-run behavior is the possible effect of transitory shocks on interest differentials. ${ }^{14}$ If, as is likely, there are differences in the magnitudes and timing of such shocks among countries, their effects are likely to spill over into real interest differentials as well as into the levels of rates within the various countries. A monetary tightening in Europe, for example, that went unmatched by similar policy changes in the United States would lead to short-term increases in European real interest rates and increases in European versus U.S. real interest differentials. Real shocks also might be expected to have short-term if not more long-lasting real-rate effects.

\section{B. Data}

In the empirical comparisons presented below, I use four bodies of data ${ }^{15}$ The first is for the long period from 1690 to 2000 and is for Dutch and English short- and long-term interest rates. The particular focus here is on the first hundred years of the sample period. Since the Dutch interest-rate data for this subperiod were only available in the form of decadal averages, I took similar averages of the English interest rates. The second body of data consists of annual series for short-term and long-term interest rates, price levels and exchange rates for eight and eleven countries, respectively. These series are of varying length depending upon the country but at their longest, they cover the period from 1800 to 2000. The eleven-country sample is made up of Belgium, Canada, France, Germany, Italy, the

${ }^{14} 0$. See Lastrapes (1998) for multi-country evidence on this subject as well as references to other studies on the subject.

15 A description of series and sources is presented in a data appendix available from the author. 
Netherlands, Norway Sweden, Switzerland, the United Kingdom, and the United States; the eightcountry sample excludes Canada, Italy and Norway. The third body of data consists of stock-price indexes for eight countries. These also vary in length by country. At their longest they also cover the full two centuries from 1800 to 2000. This eight-country sample consists of Canada, Denmark, France, Germany, Japan, Sweden, the United Kingdom, and the United States. The final body of data is for short-term interest rates and consumer price indexes as reported by the IMF for 89 countries over periods of various length during the course of the past five decades.

I estimated the real interest rates as spreads between the corresponding nominal interest rates and contemporaneous rate of inflation. I estimated real stock returns as the difference between the percentage change in the stock price index and the contemporaneous rate of inflation. The price-level data used to construct these estimates are for GNP (or GDP) deflators beginning in 1870 and linked to WPIs or CPIs, depending on data availability, before then. To reduce the measurement errors associated with such, I work almost exclusively with quinquennially averaged data. None of the results reported below depends crucially on averaging, however.

\section{C. Three Centuries of Dutch and English Real Interest Rates}

Figures $1 \mathrm{a}$ and $1 \mathrm{~b}$ and Table 2 summarize the data used in comparing Dutch and English real interest rates. Plotted in Figure 1a are decadal averages of the short-term and long-term real rates, respectively. Table 2 lists cross-country standard deviations of the two real rates by important subperiods. In all of these comparisons, data for the Napol eonic War period are missing.

The reasons for singling out these two countries are the early development of markets in tradable instruments in both countries and the close links that the historical evidence suggests existed between the two from the sixteenth century on. For the most part, the existence of such links is born out by the

data. When viewed on a long-term average basis, real short-term rates track one another amazingly well both over the entire sample period and the century from 1690 to 1879 . This is confirmed further in the low and not greatly varying standard deviations listed in Table 2. For long-term real rates the relationship, however, generally appears weaker, particularly over the 1690-1789 period.

To get at least a rough idea of what might be expected to be the case in a well-integrated market. 
I computed similar standard deviations for a U.S. treasury bill versus commercial paper and U.S. treasury bills versus Eurodollar rates for sample periods from the 1950s and 1960s through 2000. These are shown in Table 3. They were 51 and 91 basis points respectively. The corresponding ranges were 41 to 129 basis points and 37 to 125 basis points. Most of the figures in Table 2 are not out of these ranges. The averages of these figures, in fact, are 100 basis points and 107 basis points for short-term and longterm rates, respectively.

\section{D. Real-Interest-Rate Convergence in the Broader Historical Sample}

Figures 2 and 3 and Tables 4 and 5 provide an overview of real interest rate behavior in the two geographically broader historical samples. Shown in Figures $3 \mathrm{a}$ and $3 \mathrm{~b}$ are plots of cross-country average real short- and long-term interest rates and one standard deviation bounds about those averages. Shown in Figures $2 b$ and $3 b$ are plots of the cross-country standard deviations for varying groups of countries chosen according to data availability. Tables 4 and 5 list averages of cross-country standard deviations by subperiod.

Several features of these data deserve comment. The first is the commonality of movements of the various real rate series. It is clear from the means and standard deviation bounds plotted in Figures $2 \mathrm{a}$ and $3 \mathrm{a}$ that in both instances a majority of the rates moved together. That correspondence in movements is not, however, constant through time, as we can see from the varying widths of the bands and even more clearly from the cross-country standard deviations plotted in Figures $2 b$ and $3 b$ and the subperiod averages of those figures shown in Tables 4 and 5.

That gets us to the second point of interest - the time pattern of variations in these standard deviations and hence the degree to which interest rate divergences have altered over time. In both instances such variations have been substantial. In this regard, the much greater temporal homogeneity of Dutch and English experience is unrepresentative.

For both real interest rates, divergences decrease during the course of the nineteenth century and up until World War. This pattern, moreover, begins earlier and is more pronounced for the smaller groups of countries than for the larger groups. The extent to which markets are integrated quite evidently has varied not just over time but across countries at given points of time - more countries becoming 
more integrated as time has elapsed. This process, however, has certainly not been monotonic. This is evident both in the charts and the tables that were reviewed above. After reaching a low point during the period of the classical gold standard (1875-1914), the degree of interest rate divergence rises dramatically during World War I. For most of the country groups, it falls off somewhat, but remains

high, during the Interwar Years, and then rises again during World War II. Post-World War II there are returns to levels in the same general range as those observed under the gold standard, and in some instances lower.

A final point to be made has to do with the choppy nature of both sets of series over the past three to four decades. Some of this doubtless is noise, but it also is possible without stretching the case, to identify certain episodes. This is the case both in the mid-1970s and then again in the early 1990 's. Divergences in short-term real interest rates increase noticeably in the charts in both instances. The first episode very likely is associated with the move to floating exchange rates and the volatility in monetary policy, the economy and real and nominal exchange rates that surrounded that move. The second, I suspect, is related to the union of the East and West Germany, the real-interest-rate effects that resulted and the tighter German monetary policy that was pursued in its wake.

\section{E. Cointegration and Real-Interest Convergence}

Table 6 presents more formal econometric evidence on long-run behavior. The particular question it addresses is the nature of the long-term relations linking the various real interest rates, whether given pairs of real interest rates share common trends and are therefore cointegrated and convergent.

To see what these tests entail consider the cointegrating regression:

$$
r_{t}=a+b r_{t}^{*}+u_{t}
$$

where $r_{t}$ and $r_{t}{ }^{*}$ are the domestic and the for eign real interest rates, $a$ and $b$ are the cointegrating coefficients and $u_{t}$ is the error term. Suppose the constraint $b=1$ is imposed. A test for cointegration of 
the two real interest rates then becomes a test for the stationarity of the differential between them: ${ }^{16}$

$$
\mathrm{rd}_{\mathrm{t}}=\mu+\lambda \mathrm{rd}_{\mathrm{t}-1}+\eta_{\mathrm{t}}
$$

where $\mathrm{rd}_{\mathrm{t}} \equiv \mathrm{r}_{\mathrm{t}}-\mathrm{r}_{\mathrm{t}}^{*}$.

Table 6 contains the results of these regressions and the associated Dickey-Fuller tests of the hypothesis that $\lambda=1$ for both short-term and long-term real interest rates. In both sets of tests, the U.K. rate served as the numeraire. Also shown in the table for each regression is the ratio $\mu /(1-\lambda)$, the estimated long-run equilibrium differential between the respective real interest $r$ ates.

In all instances, it is possible to reject the unit root null of $\lambda=1$ at a high level of significance. The estimated values of $\lambda$ in these regressions, moreover, imply fairly rapid speeds of adjustment. The means of the estimated values of $\lambda$ are .25 and .23 , for the short-term rates and long-term rates respectively, which translate into half lives of adjustment of roughly six months in both instances. The other major items of interest in these regressions are the estimates of the intercept term, $\mu$, and of the long-tern equilibrium real-rate differential, $\mu /(1-\lambda)$. These estimates of $\mu$ are small in absolute value in almost all instances and only insignificantly different from zero in two. The associated estimates of $\mu /(1-\lambda)$ are also quite small. The median of the absolute values of $\mu /(1-\lambda)$ for the short-term rates is 68 basis points and for the long-term rates is 36 basis points. These are not only fairly small in their own right but well below the estimates of the mean differentials reported in Table 3 for U.S. money-market rates. In an alternate set of regressions, I included a set of time-period dummy variables as additional regressors. The object in doing so was to see if there were shifts in means across regimes. In general this does not appear to be the case: Viewed as a group, the dummies were statistically insignificant in all instances; viewed individually they were only significant in two cases.

16 The alternative two-step procedure to test for cointegration would be to estimate (5) using OLS and test if a first order autoregressive process of the residuals had a coefficient of $\lambda=$ 1. A value of $\lambda$ significantly less than unity would provide evidence of stationarity and hence real-rate convergence. If $\mathrm{b}$ is known to equal unity, then the procedure used here results in a more powerful test. 
These results, therefore, strengthen the conclusions reached earlier with regard to financial integration and real-interest equalization. Real interest rates do in fact appear to converge, if not to differentials of zero, to differentials that in most instances are small in absolute value and not much different from those observed in integrated U.S. markets. The differentials in most instances also appear temporally stable.

\section{F. UIP and Nominal Interest-Rate Convergence}

An alternative measure of integration that focuses on financial markets directly can be derived from the UIP relation. According to UIP:

$$
\hat{\mathrm{s}}_{\mathrm{t}}^{*}=\mathrm{R}_{\mathrm{t}}-\mathrm{R}_{\mathrm{t}}^{\mathrm{F}}
$$

the anticipated change in the exchange equals the nominal interest differential. This in turn implies that equality between the domestic nominal interest rate and exchange-rate adjusted foreign nominal interest rate

$$
\mathrm{R}_{\mathrm{t} .}=\hat{\mathrm{s}}_{\mathrm{t}}^{*}+\mathrm{R}_{\mathrm{t}}^{\mathrm{F}}
$$

which under fixed exchange rates translates into equality of the two nominal rates. The advantage of this measure relative to the real-interest differential is that errors in expectations of inflation do not enter in. It is, therefore, well suited to comparisons in periods in which exchange rates are stable. In periods of floating exchange rates, errors in expectations with regard to the path of the nominal exchange rate obviously can play a role. In this instance, what is taken in with one hand is, therefore, given back with the other.

The evidence using the deviation from UIP as a measure of financial integration is summarized in Figure 4 and Table 7. Plotted in the chart are the spreads between French, Belgian, Dutch and U.S. nominal short-term rates and the exchange-rate-adjusted short-term U.K. nominal rate. I have omitted the other three rates from the chart to keep it simple, but they tell roughly the same story. 
Listed in the table are means and standard deviations of the exchange-rate-adjusted spreads for each of the subperiods individually and for all of them taken as a group. The feature of the chart that stands out is the substantial difference in behavior between the long period in the nineteenth century in which commodity monies were used, and hence in which fixed exchange rates prevailed, and the periods of exchange rate volatility in the twentieth century associated with wars and the post-Bretton woods float. In the nineteenth century, these spreads in the main are relatively small and quite stable. During the two world wars of the twentieth century and in the inter-war period, behavior appears quite different. In all three of these episodes, wide and variable spreads were typical suggesting that the exchange-rate changes were largely unanticipated. Post-World War II, the exchange-rate-adjusted spreads are narrower but still quite variable. The other feature of the chart that is of some interest is the difference between U.S. and European interest rates in the early nineteenth century. ${ }^{17}$ This could simply be due to a heightened risk of financial crises in the U.S. relative to Europe, or it could be caused by weaker links between the U.S. and Europe than among European economies and markets.

Despite the often problematic behavior of UIP in the short run, it appears to have held tolerably well over longer periods. ${ }^{18}$ In this regard, the real-interest comparisons and UIP tell a similar story. We can see this in both the means for the full periods and the means for the subperiods in Table 7 . In both instances, these are almost always small fractions of the corresponding yearly standard deviations. The one exception is the United States in the two nineteenth-century subperiods, but even here the means are less than twice the associated standard deviation. In no instance, therefore, can we reject the null hypothesis of a zero mean using a conventional $t$ test. Viewed from the standpoint of economic significance, the data tell a largely similar story. In roughly half the cases, the subperiod means are less than 100 basis points in absolute value. The same thing is true for six of the seven full-period means.

17 Additional work on the behavior of UIP historically is reported in Lothian and Wu (2002). See also Kugler and Weder (2002).

18 For further evidence on UIP performance in both the short and long runs see Chinn and Meredith (2002), Kugler and Weder (2000), Lothian and Simaan (1998), and Lothian and $\mathrm{Wu}(2002)$. 


\section{G. Real Stock Returns}

Since it is impossible to get dividend data for more than a few countries for long periods, I have used the percentage change in real stock prices as a proxy for real stock returns. Figures $5 \mathrm{a}$ and $5 \mathrm{~b}$ and Table 8 summarize the behavior of these data.

Real stock returns in many ways behave very similarly to real interests rates. Returns are less variable across the two smaller groups of countries than across the larger, the degree of divergence varies over time, wars clearly increase such divergences, and the classical gold standard period and the past several decades mark relative low points in the degree of divergence. There are, however, two differences that stand out. The first is the much greater cross-country divergence of real stock returns than of real interest rates, either short or long. The second, and this is more puzzling, is the much less noticeable effect of Interwar disruptions on stock returns as opposed to interest rates. Divergences generally are higher during those years than under the gold standard but not much different from in recent years.

As a standard of comparison I again used U.S. data, computing cross-index standard deviations of returns from the S\&P 500, the Dow Jones Industrial Average and the NASDAQ index for the periods 1940-2000 and 1960-2000. These figures, which are shown in Table 3, were both roughly 300 basis points. This is in the lower part of the range of figures reported for cross-country stock-return divergences in Table 8. It is, however, substantially greater than the figures reported for U.S. interest rates in Table 3. This disparity is consistent with risk involved in holding equities being greater than the risk involved in holding bonds. It is possible that risk premia also explain the much greater difference between divergences in cross-country stock-returns and cross-country divergences in real interest rates.

These results raise an additional issue, however. In all of the comparisons the possibility arises that what has been captured is simply variations in real interest rates and real stock returns brought about by variations of domestic variables that affect the real returns to physical assets within an autarchic world. There are three problems with that reasoning. The first is that it does not square with what we otherwise know about the economic history of the past two centuries. The gold standard period by all measures was a period of substantial economic and financial openness. Financial markets, in particular, 
were well developed and, it appears, rather closely linked. ${ }^{19}$ The second is the behavior of macroeconomic variables over this period. Purchasing power parity over the long-term held quite well (see inter alia Lothian and Taylor, 1996). Under fixed exchange rates, inflation rates were very similar across countries; under floating rates exchange rate changes on average followed inflation differentials. The third stems from what international trade data tell us about the various periods.

In Figure 6, I have reproduced a chart from Lothian (2000) that extends the work of Grassman (1980). Shown in the chart are ratios of imports plus exports to GNP for the original five countries from Grassman's sample plus four more of those studied in this paper and my earlier paper. The time patterns are clearly quite similar to those that we see un the charts for real interest rates and to a lesser extent also real stock prices - substantial openness under the classical gold standard and recently and the reverse in World War I, World War II and the Interwar Period.

\section{H. Real-Interest-Rate Behavior in Recent Decades}

Let me now turn to a related issue, the spread of integrated markets in recent decades and geography of globalization. Casual observation suggests that even thought the strength of the links among financial markets still is a good deal weaker in some parts of the world than in others it is nevertheless much greater now than even two decades ago.

A very basic indicator of the extent of this change is data availability. In economics it is standard usage to refer to the data that are used in empirical investigation as "the sample." In the context of the interest-rate comparisons presented above, the term is a complete misnomer. Until the past few decades the small group of countries studied there were virtually the only countries for which one could obtain time series on interest rates. In the rest, organized markets simply did not exist. Today the situation is dramatically different. The interest rate data published by the International Monetary Fund that I use below span 89 countries, and that is after elimination of a fair number of countries with missing observations or only very short time series. This stands in clear contrast to the groups of 8 and 11

19 See O'Rourke (2002) for a concise historical overview of globalization. Lothian (1997), Lothian (2000), and Obstfeld and Taylor (2002) present a variety of different types of evidence with regard to its financial dimensions. 
countries for which long-term time series data are available.

Shown in the five panels of Figure 7 are plots of cross-country standard deviations of annual expost short-term real interest rates for this group of 89 countries for various subperiods during the past 50 years chosen on the basis of data availability. The first four panels plot the cross-country standard deviations of these data for four subgroups individually: OECD members, Asia-Pacific, Africa, and Latin America-Caribbean. The last plots standard deviations taken across the means of these four subgroups.

Two features of these charts stand out. The first are the substantial cross-country divergences observed within the three periphery country groups as well as across the four groups over the sample period. The second is the generally smaller cross-country divergence observed in four of five cases during the 1990s as opposed to earlier. The implications in each instances are straightforward. Integration clearly has been and for the most part still is much less complete within the periphery than within the core but, nevertheless, is increasing. Indeed, for the periphery versus the core on average, it appears not much different from the major countries examined above.

\section{Conclusions}

"Nothing under the sun is new, neither is any man able to say: Behold this is new: for it hath already gone before in the ages that were before us." In international finance, as in many other areas, Ecclesiates' dicta contains much truth.

A global financial marketplace is not something that has just recently appeared. In one form or another, it has been around for centuries, if not in fact for more than a millennium. That is the principal message that comes out of this paper.

From the fourth century and into the later Medieval period international finance meant facilitating international trade - providing a means of payment that could be used in international trade. For five centuries or more this, in turn, translated into the establishment of a coinage that was stable and not subject to debasement and that was otherwise reliable. This early coinage, the bezant, was struck initially during the reign of Constantine and coined continuously thereafter in Byzantium through the eleventh century.

Shortly after that banking began to develop and the bill of exchange and its predecessor the 
instrumentum ad cambium were introduced, the principal stimulus again being international payment. Because settlement using such instruments was delayed, their issuance also entailed credit extension. This, along with deposit-taking and giro transfers, became a second major function of the early banking firms. Because much of the business of these firms was cross-border they established branch networks like those of modern bank holding companies. Not surprisingly, negotiable instruments and markets in which they could be traded came next. ${ }^{20}$

Data exist for such markets beginning in the late seventeenth century and those data tell very much the same story as the earlier historical evidence. Throughout the three hundred plus years for which there are data for interest rates, and the two hundred years for which there are data for stock returns, we see behavior similar to that observed in today's global markets. This is true of the eighteenth century, much of the nineteenth century - the classical gold standard era particularly - and the early and late twentieth century. Wars and other disruptions, most notably the Great Depression of the 1930s and the reactions thereto, interrupted and reversed the integration process, but then it began all over again. The prospect of gains from trade quite evidently exerts a powerful force.

The differences in international financial arrangements over the course of the long period examined in this paper have been substantial, but these differences have been more differences in degree than in kind. The number of markets and types of ins truments issued and traded has grown enormous ly, even during the course of the last three decades. Information is now transmitted in seconds rather than in days, weeks or months. Many more parts of the globe have such markets than even a few decades ago. The general thrust toward internationalization, however, is not new, nor are the basics of how international markets operate.

${ }^{20}$ See the review of this history in Kohn (2001). 


\section{References}

Ashton, T.S. 1955. An Economic History of England: The $18^{\text {th }}$ Century, Barnes and Noble, New York.

Bordo, M.D., Eichengreen, B., Kim , J. 1998. Was There really an earlier period of international financial integration comparable to today? National Bureau of Economic Research Working Paper No. W6738, Cambridge, MA.

Bordo, Michael D., 2000, The globalization of financial markets: What can history teach us? Paper presented at the Conference on International Financial Markets: The Challenge of Globalization, at Texas A and M University, College Station, Texas.

Center for Medieval and Renaissance Studies, University of California, Los Angeles. 1979. The Dawn of Modern Banking, Yale University Press, New Haven .

Chinn, M., Meredith, G. 2001. Testing uncovered interest parity at short and long horizons. Unpublished working paper. University of California at Santa Cruz, Santa Cruz, CA.

Chon, J.F. 1994. The History of Money from AD 800. Routledge, London.

Cipolla, C. M. 1963, Currency depreciation in medieval Europe. Economic History Review, 15, 413422.

Cipolla, C. M. 1967. Money, Prices, and Civilization in the Mediterranean World, Fifth to Seventeenth Century. Gordian Press, New York.

Dehing, P., 't Hart, M. 1997. Linking the fortunes: currency and banking, 1550-1800, In: a Financial History of the Netherlands, In: 't Hart, M. , Jonker, J., van Zanden, J.L. Cambridge University Press, Cambridge and New York, pp. 37-63.

De Roover, R. 1974. Business, Banking, and Economic Thought in Late Medieval and Early Modern Europe, Selected Studies of Raymond de Roover. Ed., Julius Kirshner.. University of Chicago Press, Chicago.

De Roover, R. 1963. The Rise and Decline of the Medici Bank, 1397-1494. Harvard University Press, Cambridge, MA.

Dwyer, G.P. Jr., Lothian, J.R., 2002 in press. International money and common currencies in historical perspective. In: von Furstenberg, G.M. (Ed.), The Euro and Dollarization: Forms of Monetary Union in Integrating Regions. Oxford University Press, Oxford.

Eagly, R., Smith, V.K. 1976. Domestic and international integration of the London Money market, 17311789, Journal of Economic History. 36, 198-212.

Einzig, P. 1970. The History of Foreign Exchange, 2nd ed. Macmillan, London.

Feavearyear, A. E. 1963. The Pound Sterling; A History of English Money, 2nd ed.. Revised by E. Victor Morgan. Oxford University Press, Oxford.

Fisher, I. 1962. The Rate of Interest. Reprint of the 1907 edition with a new introduction by Donald Dewey. Garland Publishing, New York. 
Friedman, M., Schwartz, A.J. 1982. Monetary Trends in the United States and the United Kingdom. University of Chicago Press for the National Bureau of Economic Research, Chicago.

Frankel, J. A. 1992. Measuring international capital mobility: A review. American Economic Review. 82, 197-202.

Gilson, E. 1991. The Spirit of Medieval Philosophy. University of Notre Dame Press, Notre Dame, IND.

Goldberg, L., Lothian, J.R. , Okunev, J. 2001. Has international financial integration increased? Unpublished working paper. Schools of Business, Fordham University, New York, NY.

Goodwin, B. K., Grennes, T. J. 1993. Real interest rate equalization and the integration of international financial markets. Journal of International Money and Finance. 12, 107-124.

Grassman, S. 1980. Long-term trends in openness of national economies, Oxford Economic Papers, 32, 123-133.

International Monetary Fund, International Financial Statistics, various issues.

Homer, S., Sylla, R. 1996. A History of Interest Rates, $3^{\text {rd }}$ ed. revised. Rutgers University Press, New Brunswick, NJ.

Jackson, P. S., Lothian, J.R. 1993. The behavior of bond yields across exchange-rate regimes and the integration of capital markets. Greek Economic Review. 15, 1-28.

Johnson, D.R. 1992. International interest rate linkages and the exchange rate regime, Journal of International Money and Finance, 11, 340-365.

Kohn, M. 2001. Payments and the development of finance in pre-industrial Europe. Unpublished working paper. Dartmouth College, Hanover, NH.

Lastrapes, W.D. 1998. International evidence on equity prices, interest rates and money, Journal of International Money and Finance, 17, 377-406

Kugler, P. Weder, B. 2002. The failure of long-run uncovered interest rate parity for Swiss franc assets, Unpublished working paper. University of Basle, Basle.

Lopez, R. S. 1951. The Dollar of the middle ages, Journal of Economic History, 11, 209-234.

Lopez, R.S. 1956. The return to gold 1252. Economic History Review, N.S. 89, 219-240.

Lopez, Robert S. 1986. The Shape of Medieval Monetary History. Variorum Reprints, London.

Lothian, J.R. 1997. The reinternationalization of banking and the financial system, Managerial Finance, $23,25-41$.

Lothian, J.R. 2000. Capital market integration and exchange rate regimes in historical perspective. In: Hasan, I., Hunter, W.C. (Eds.), Research in Finance and Banking, 1, Elsevier Science, New York.

Lothian, J.R..2002 in press. Exchange rates. Oxford Encyclopedia of Economic History. Oxford University Press, New York.

Lothian, J.R., Simaan, Y. 1998. International financial relations under the current float: evidence from 
panel data. Open Economies Review. 9, 293-313.

Lothian, J.R. , Taylor, M.P. 1996. Real exchange rate behavior: the recent float from the perspective of the past two centuries. Journal of Political Economy. 104, 488-509.

Lothian, J.R., Wu, L. 2002. Uncovered interest parity: the long view. Unpublished working paper. Schools of Business, Fordham University, New York, NY.

Marston, R. C. 1994. International Financial Integration: A Study of Interest Differentials Between the Major Countries. Cambridge University Press, Cambridge.

Michie, R.C., 1987. The London and New York Stock Exchanges, 1850-1914. Allen and Unwin, London.

Neal, L. 1990. The Rise of Financial Capitalism. Cambridge University Press, Cambridge:

Obstfeld, M., Taylor, A.M. 1998. The Great Depression as a Watershed: International Capital Mobility over the Long Run. In: Bordo, M.D., Goldin, C., White, E.N. (Eds.), The Defining Moment: The Great Depres sion and the American Economy in the Twentieth Century. University of Chicago Press for the National Bureau of Economic Research, Chicago, pp. 353-402.

Obstfeld, M., Taylor, A.M. 2002 in press. Globalization and capital markets. In: Bordo, M.D., Taylor, A.M., Williamson, J.G. Globalization in Historical Perspective. University of Chicago Press for the National Bureau of Economic Research, Chicago.

O'Rourke, K. H. 2002 forthcoming. Europe and the causes of globalization, 1790 to 2000. In: Kierzkowski, H. (Ed.), From Europeanization of the Globe to the Globalization of Europe. Palgrave, New York.

O'Rourke, K. H., Williamson, J.G. 2000. When did globalization begin? National Bureau of Economic Research Working Paper No. W7632, Cambridge, MA.

Pirenne, Henri. 1936. Economic and Social History of Medieval Europe. K. Paul, Trench, Trubner and co., ltd, London.

Rousseau, P.L., Sylla, R.E. 2002 forthcoming. Financial systems, economic growth, and globalization, In: Michael D. Bordo, Alan M. Taylor and Jeffrey G. Williamson (Eds.), Globalization in Historical Perspective. University of Chicago Press for the National Bureau of Economic Research, Chicago.

Schumpeter, J. A. 1954. History of Economic Analysis. Oxford University Press, New York.

Spufford, P., with the assistance of Wilkinson, W., Tolley, S. 1986. Handbook of Medieval Exchange. Woodbridge for the Royal Historical Society, London.

Spufford, Peter. 1988. Money and its Use in Medieval Europe. Cambridge University Press: Cambridge and New York.

Taylor, A.M. 2002. A century of current account dynamics. Journal of International Money and Finance, $21,000-000$.

von Furstenberg, George M. 1998. From Worldwide Capital Mobility to International Financial Integration, Open Economies Review. 9, 53-84. 
Fig.1a. Real short-term interest rates 10 -year averages

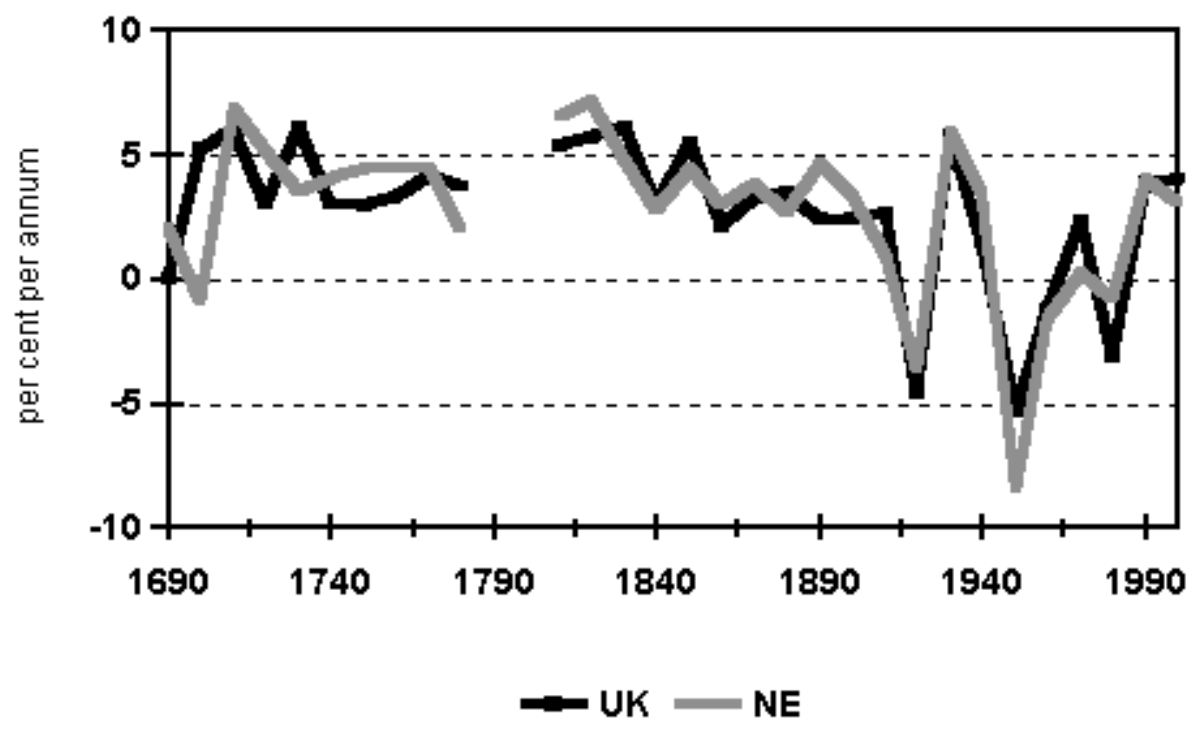

Fig. 1b. Real long-term interest rates 10 -year averages

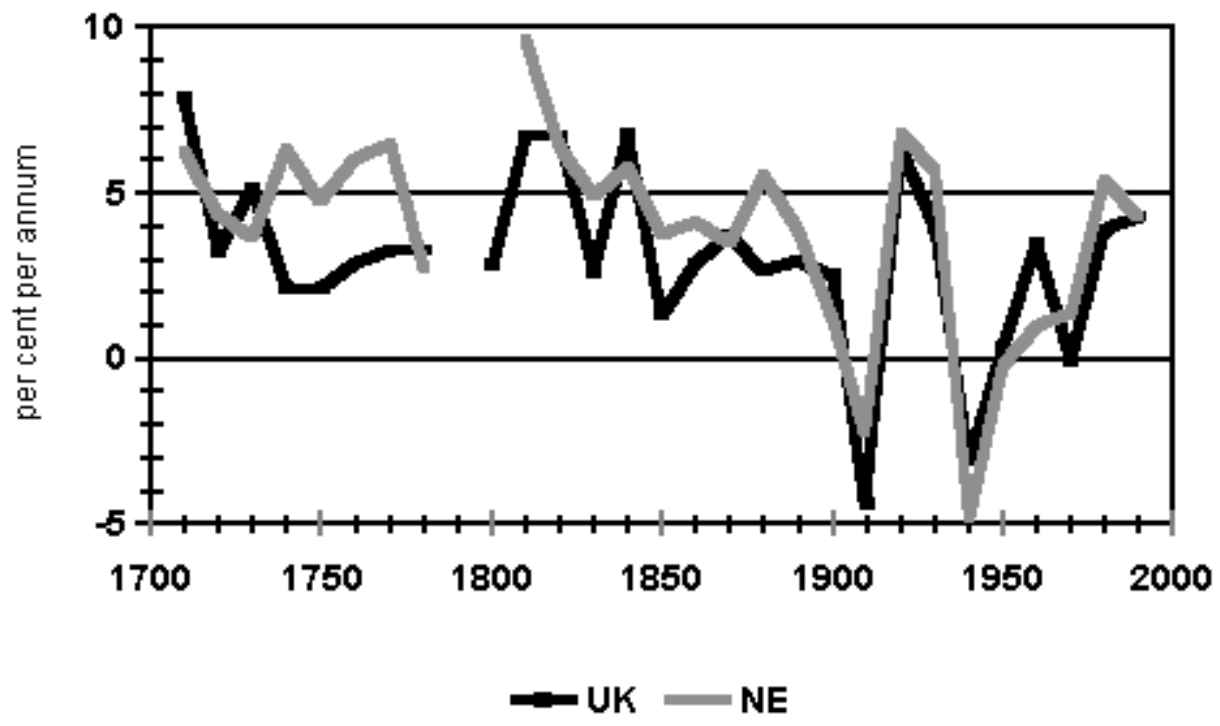


Fig.2a. Real short-term interest rates means of 5-year averages

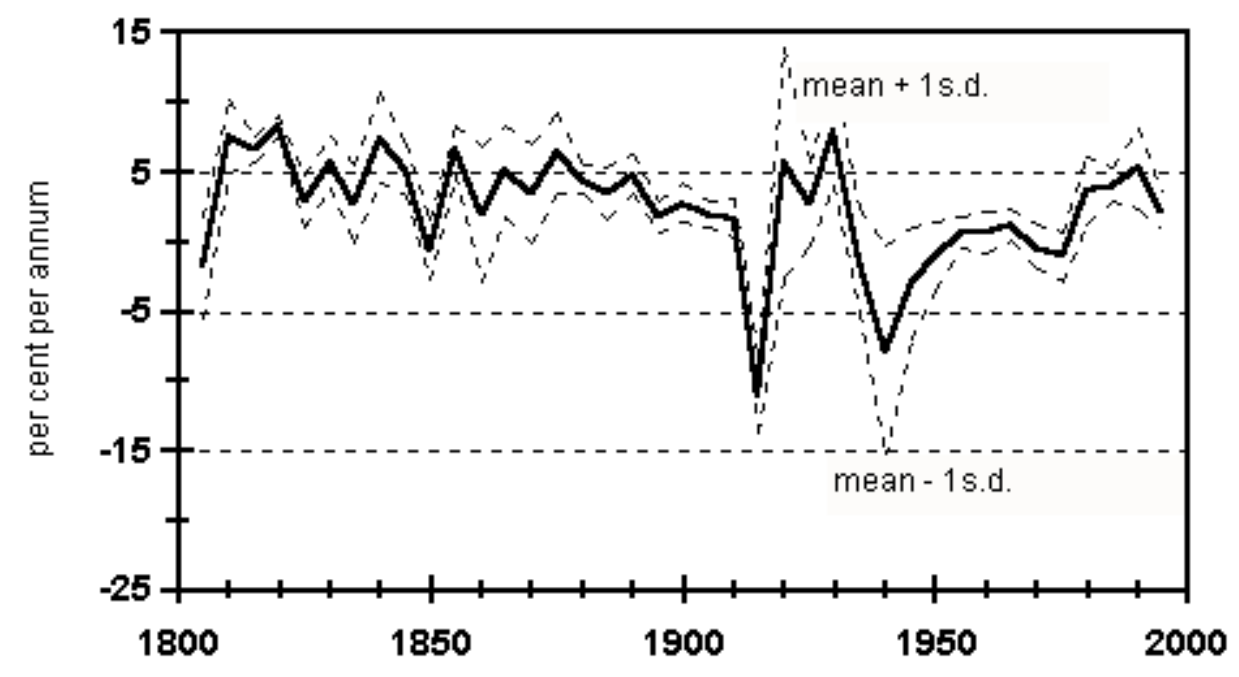

Fig.2b. Real short-term interest rates standard deviations of 5-year averages

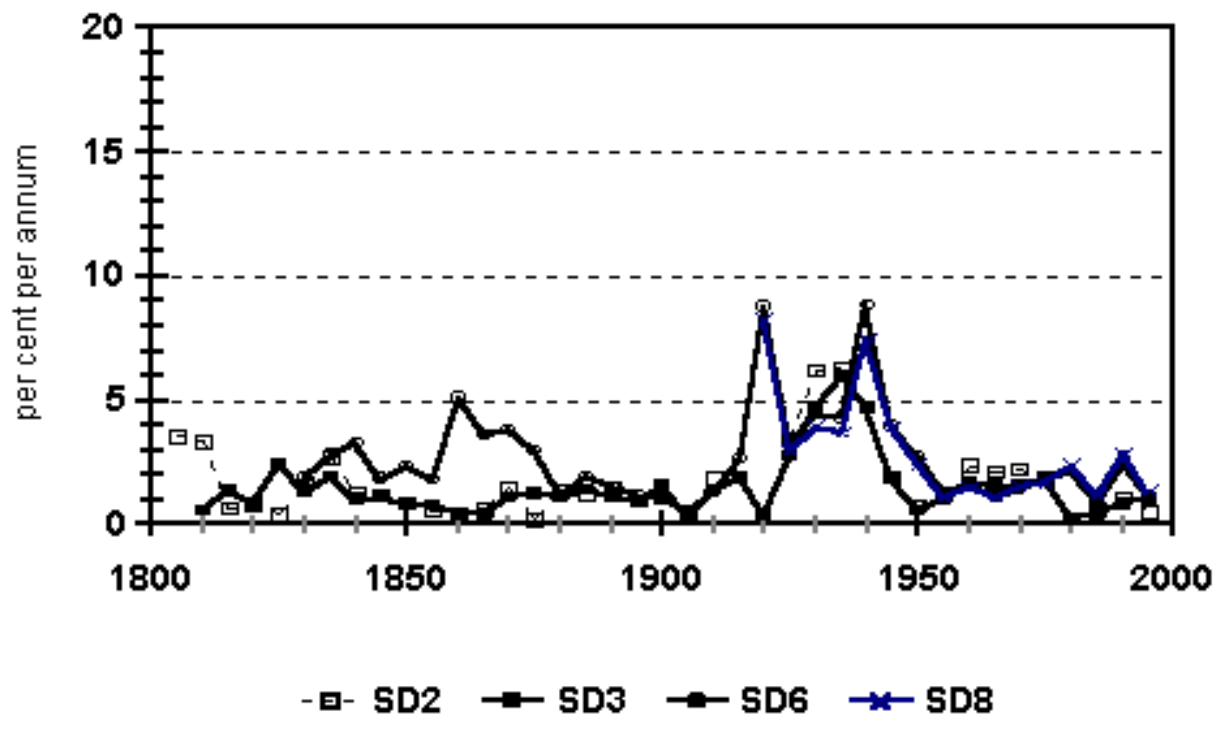


Fig. 3a. Real long-term interest rates means of 5-year averages

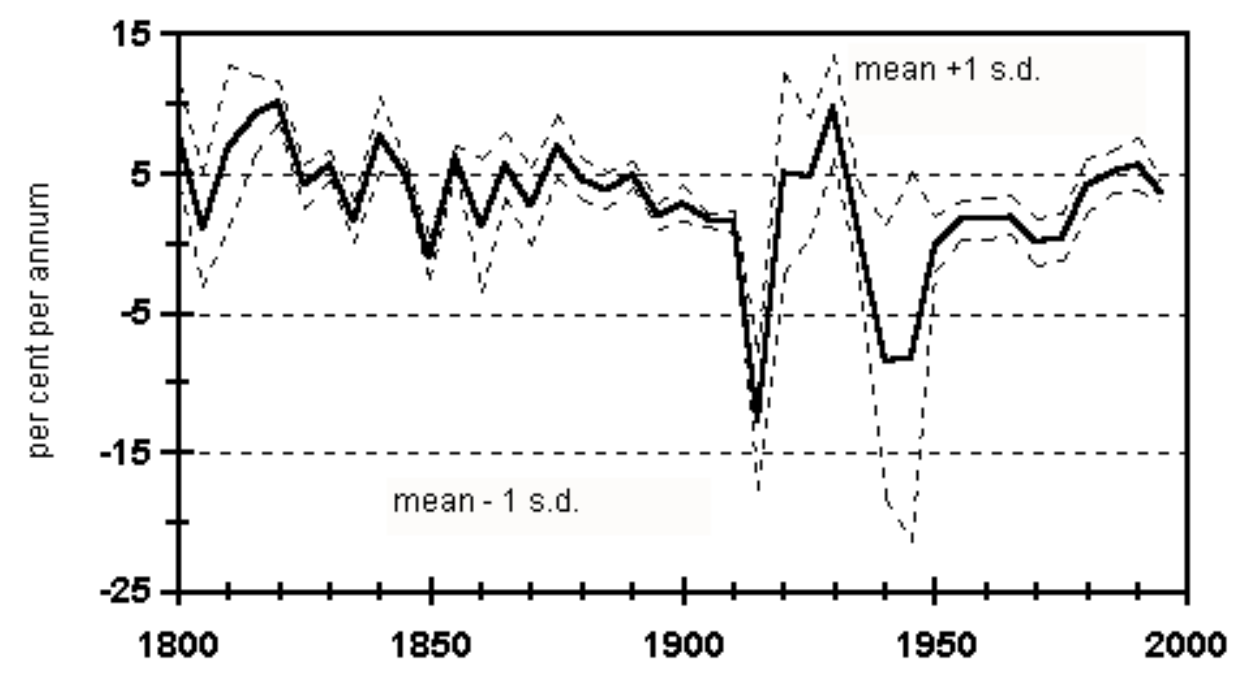

Fig. 3b. Real long-term interest rates standard deviations of 5-year averages

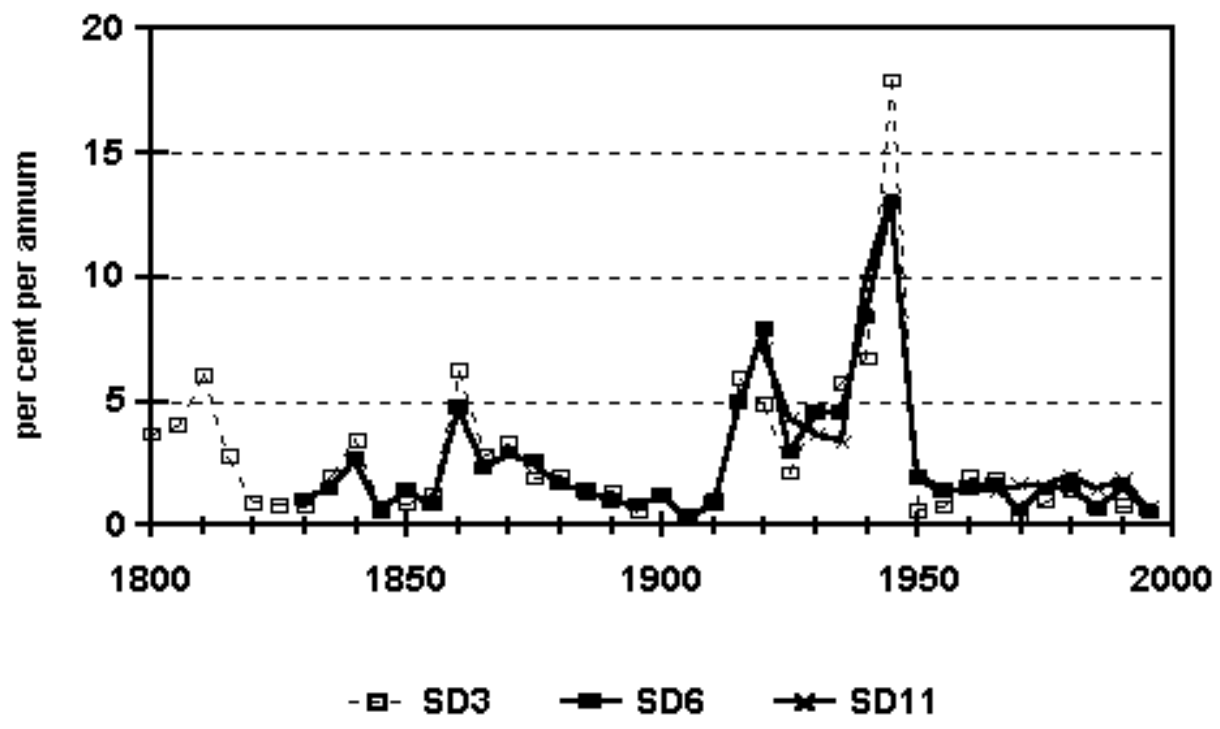


Fig.4. Deviations from UIP foreign vs. UK short-term rates

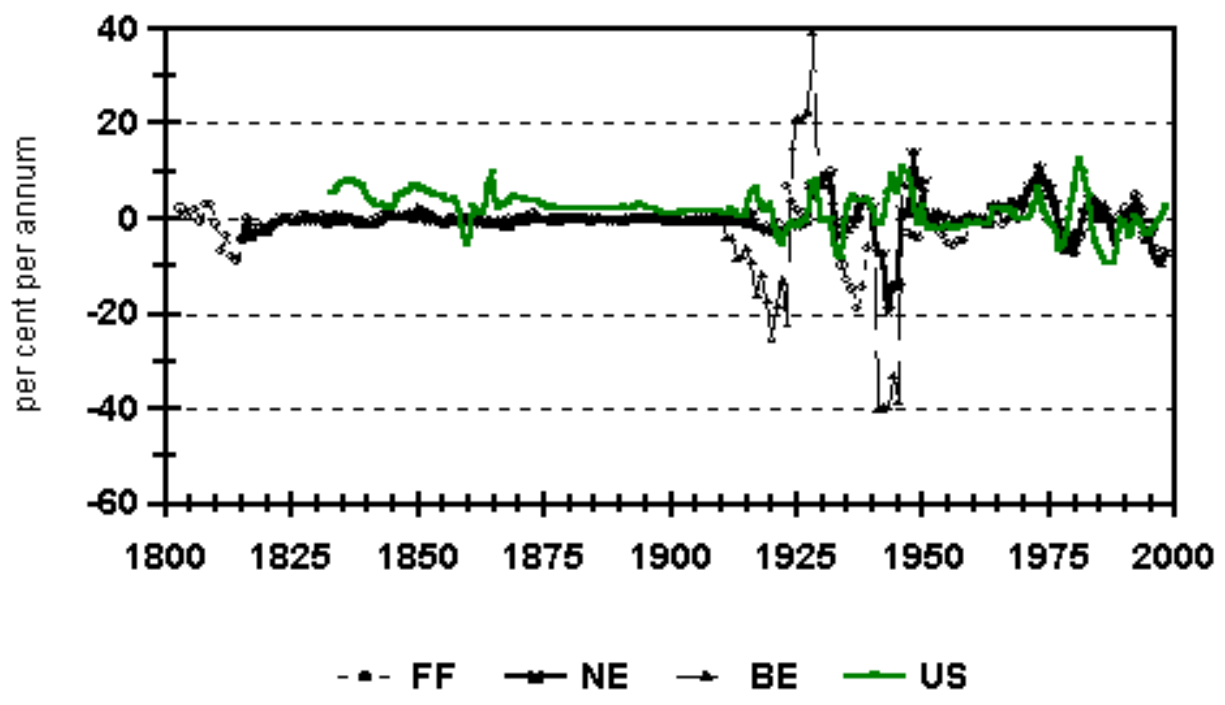


Fig.5a. Real stock returns means of 5-year averages

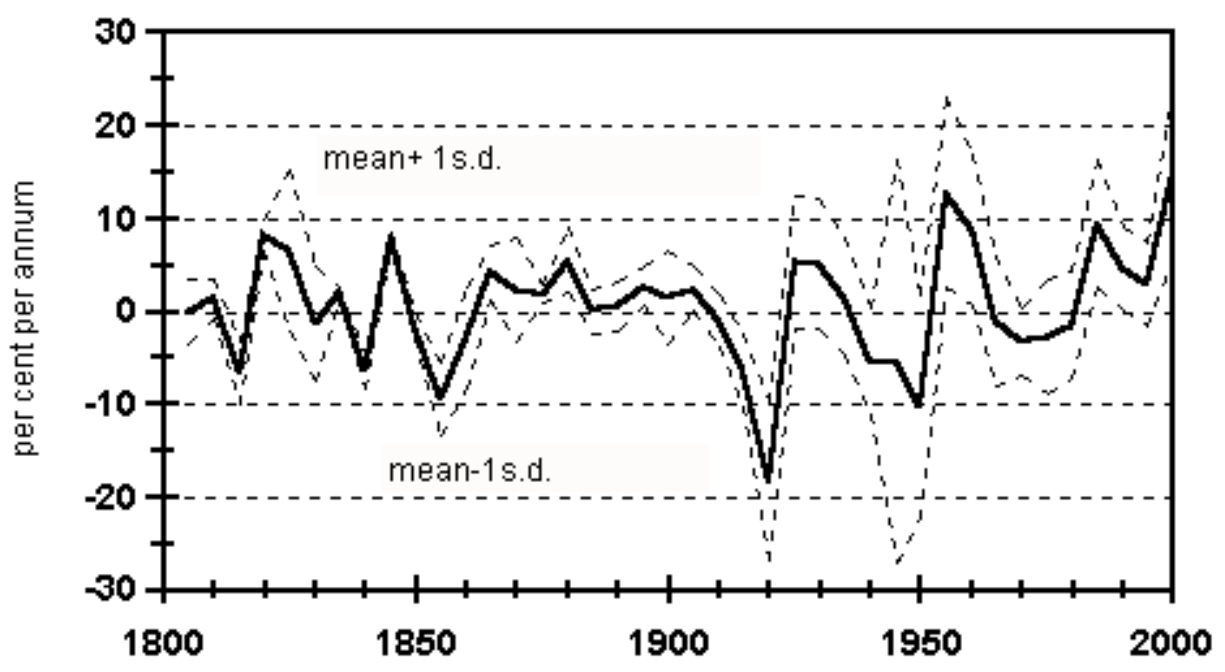

Fig.5b. Real stock returns standard deviations of 5 -year averages

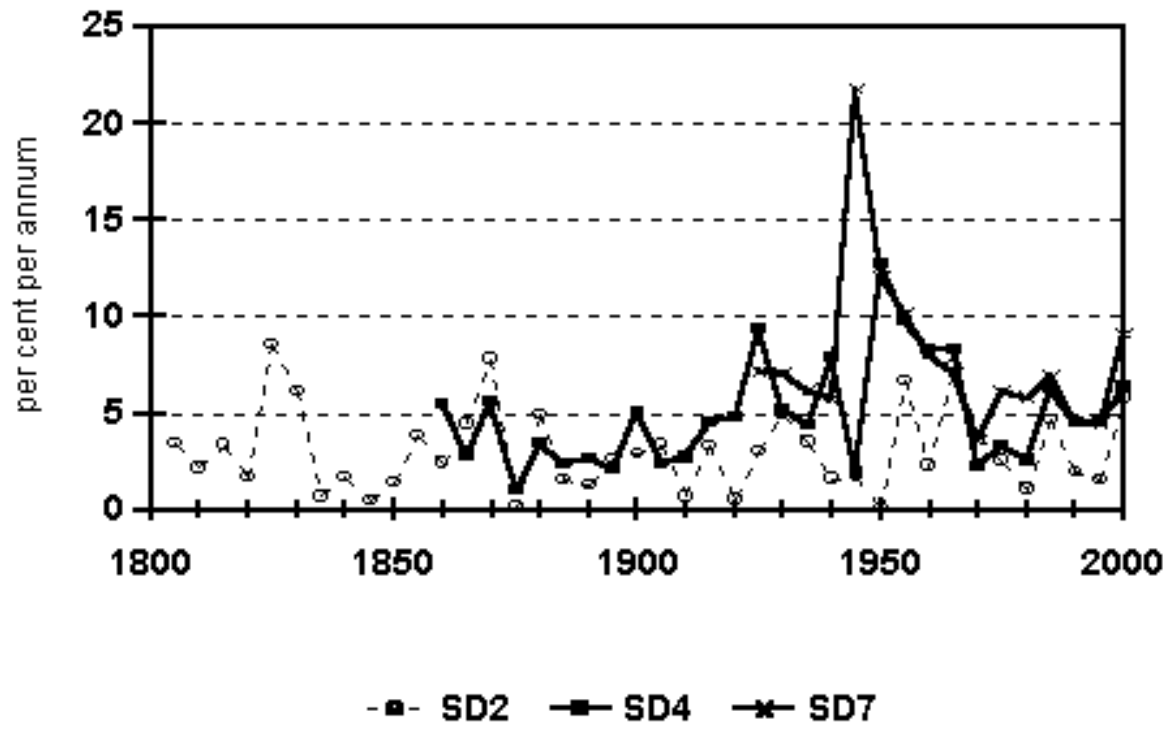


Fig. 6. Sum of imports and exports as a ratio to $\mathbf{G N P}$, decadal averages

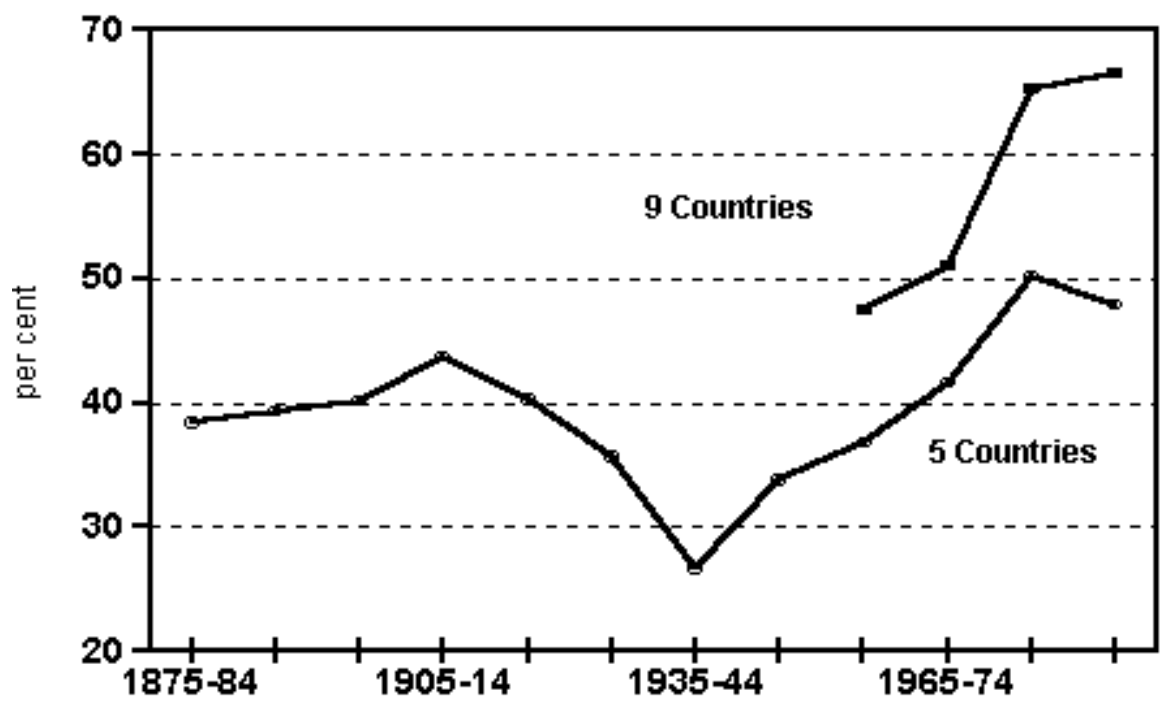


Fig. 7. Cross-country standard deviations of short-term real interest rates, post-WWII IMF data

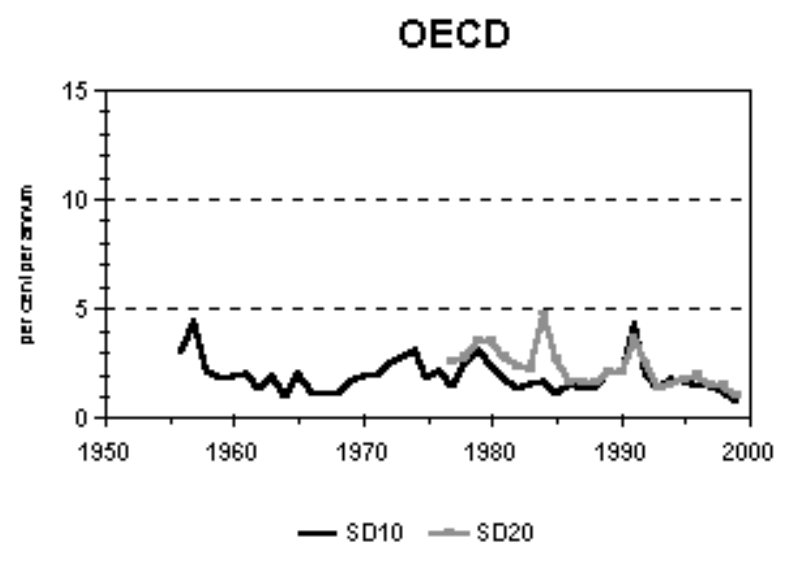

Fig. $7 \mathbf{a}$

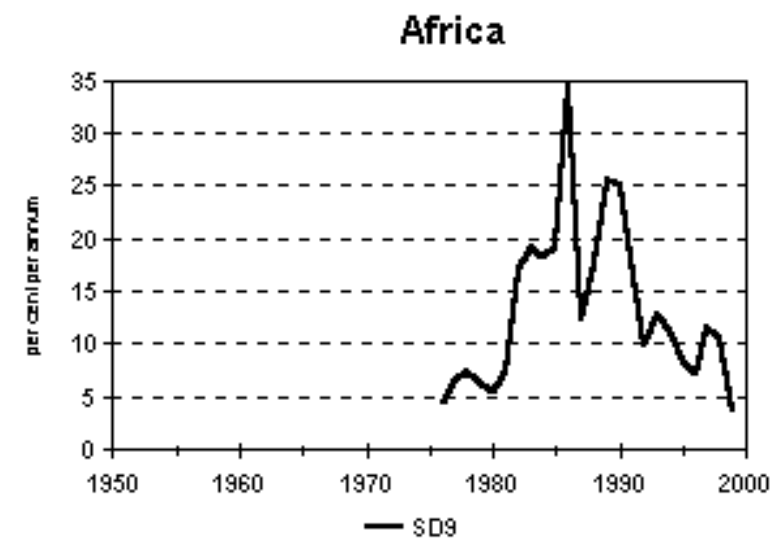

Fig. 7c

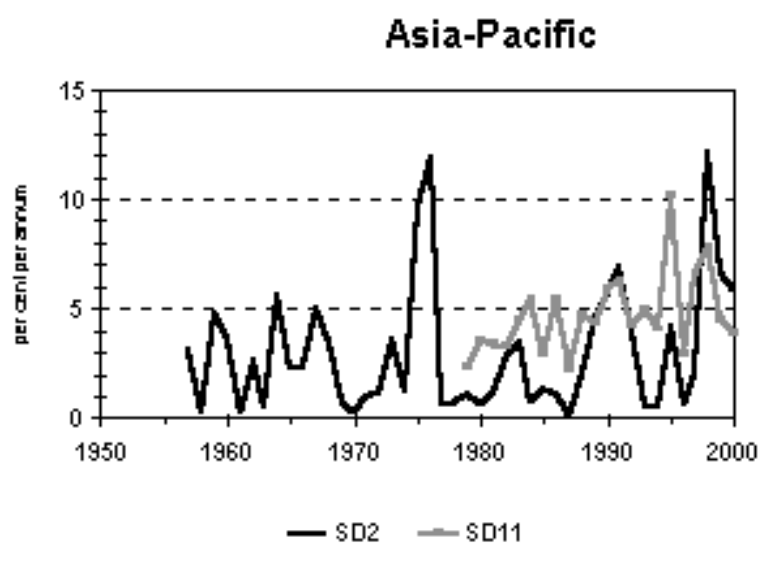

Fig. $7 b$

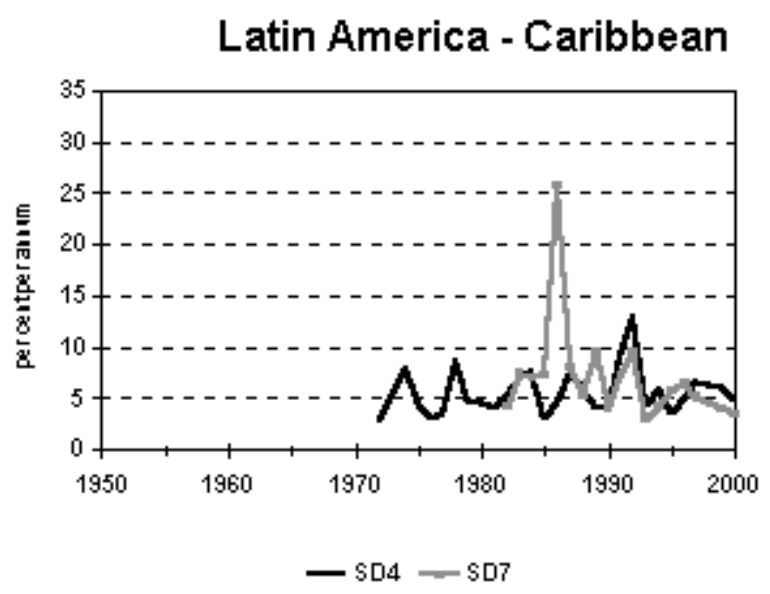

Fig. 7d

\section{Country Groups}

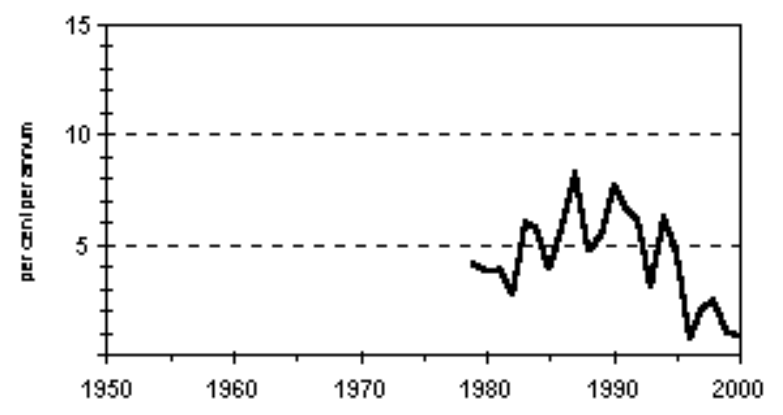

Fig. 7e 
Table 1. Exchange rate depreciation and currency debasement, 1250 to 1500

\begin{tabular}{lrr}
\hline & $\begin{array}{r}\text { Debasement } \\
\text { (per cent change) }\end{array}$ & \multicolumn{2}{c}{$\begin{array}{c}\text { Exchange rate } \\
\text { (per cent change) }\end{array}$} \\
\hline England & 63.3 & 60.6 \\
France & 129.1 & 157.8 \\
Genoa & 168.4 & 209.2 \\
Milan & 205.1 & 219.7 \\
Venice & 120.4 & 94.9 \\
Florence & 176.4 & 181 \\
\hline
\end{tabular}

Sources: Cippola (1963)and Spufford (1986).

Table 2. Dutch and English real interest rates:

Subperiod averages of cross-country deviations of decadally averaged data

\begin{tabular}{cccc}
\hline Period & Short-term & Period & Long-term \\
\hline $1690-1789$ & 1.38 & $1710-1789$ & 1.59 \\
$1810-1849$ & 0.76 & $1810-1849$ & 1.15 \\
$1850-1869$ & 0.70 & $1850-1869$ & 1.31 \\
$1870-1909$ & 0.97 & $1870-1909$ & 0.99 \\
$1910-1919$ & 1.20 & $1910-1919$ & 1.53 \\
$1920-1939$ & 0.42 & $1920-1939$ & 0.94 \\
$1940-1949$ & 1.39 & $1940-1949$ & 0.34 \\
$1950-1970$ & 1.20 & $1950-1970$ & 1.06 \\
$1970-2000$ & 0.98 & $1970-2000$ & 0.73 \\
\hline
\end{tabular}

Sources: See appendix. 
Table 3. Standard deviations of five -year averages of U.S. stock returns and interest rates

\begin{tabular}{rrrrr}
\hline & $\begin{array}{l}\text { Interest rates } \\
\text { CP, t-bill }\end{array}$ & Euro \$, t-bill & & $\begin{array}{r}\frac{\text { Stock returns }}{\text { S\&P500, DJIA, }} \\
\text { NASDAQ }\end{array}$ \\
\hline $1940-2000$ & 0.51 & & $1957-2000$ & 2.94 \\
$1960-2000$ & 0.51 & 0.93 & $1963-2000$ & 3.10 \\
\hline
\end{tabular}

Sources: See appendix.

Table 4. Short-term real interest rates: Subperiod averages of cross-country standard deviations of quinquennially averaged data

\begin{tabular}{ccccccc}
\hline Period & SD2 & SD3 & SD5 & SD6 & SD7 & SD8 \\
\hline $1800-1814$ & 2.76 & 0.56 & & & & \\
$1815-1849$ & 1.25 & 1.44 & 2.71 & 2.46 & & \\
$1850-1874$ & 0.81 & 0.71 & 3.66 & 3.33 & 3.16 & \\
$1875-1914$ & 1.09 & 1.13 & 1.53 & 1.47 & 1.50 & \\
$1915-1924$ & & 1.15 & 1.48 & 5.73 & 5.90 & 8.26 \\
$1925-1939$ & 5.35 & 4.49 & 3.57 & 4.00 & 3.80 & 3.57 \\
$1940-1949$ & 1.97 & 3.27 & 3.25 & 6.41 & 6.15 & 5.73 \\
$1950-1974$ & 1.74 & 1.30 & 1.53 & 1.64 & 1.52 & 1.54 \\
$1976-2000$ & 0.88 & 0.89 & 1.30 & 1.70 & 1.69 & 1.90 \\
\hline
\end{tabular}

Sources: See appendix.

Notes: The eight countries listed in order of their inclusion are the United Kingdom, France, the Netherlands, the United States, Germany, Belgium, Sweden and Switzerland.

The symbols SD2 through SD8 indicate the number of countries (in the order indicated above) used in computing the standard deviations.

The years and countries for which data are missing are as follows: France, 1915-24 and 1939-48; the Netherlands 1942-45; Belgium,1915-18 and 1941-47; Germany, 1920-24 and 1945-49. 
Table 5. Long-term real interest rates: Subperiod averages of cross-country standard deviations of quinquennially averaged data

\begin{tabular}{cccccc}
\hline Period & SD3 & SD5 & SD6 & SD10 & SD11 \\
\hline $1800-1814$ & 4.62 & & & & \\
$1815-1849$ & 1.64 & 2.48 & 1.47 & & \\
$1850-1874$ & 2.94 & 1.86 & 2.47 & 2.81 & \\
$1875-1914$ & 1.26 & 1.53 & 1.26 & 1.17 & \\
$1915-1924$ & 5.43 & 8.90 & 6.44 & 6.14 & 7.19 \\
$1925-1939$ & 4.20 & 3.51 & 3.99 & 3.96 & 3.79 \\
$1940-1949$ & 12.37 & 13.69 & 10.69 & 11.95 & 11.58 \\
$1950-1974$ & 1.14 & 1.39 & 1.44 & 1.61 & 1.59 \\
$1976-2000$ & 0.91 & 2.09 & 1.22 & 1.34 & 1.55 \\
\hline
\end{tabular}

Sources: See appendix.

Notes: $\quad$ The eleven countries listed in order of their inclusion are the United Kingdom, France, the United States, the Netherlands, Germany, Belgium, Canada, Italy, Norway, Sweden and Switzerland. 
Table 6. Regression and test results for real inter est differen tials relative to U.K.

\begin{tabular}{|c|c|c|c|c|c|c|}
\hline & nobs & $\mu$ & $\lambda$ & $\overline{D F}$ & $\mathrm{R}^{2} / \mathrm{SEE}$ & $\mu /(1-\lambda)$ \\
\hline \multicolumn{7}{|c|}{ Short-term rate } \\
\hline France & 176 & $\begin{array}{l}-0.162 \\
-0.321\end{array}$ & $\begin{array}{l}0.082 \\
1.119\end{array}$ & 12.572 & $\begin{array}{l}0.007 \\
6.687\end{array}$ & -0.176 \\
\hline Netherlands & 170 & $\begin{array}{l}-0.039 \\
-0.094\end{array}$ & $\begin{array}{l}0.213 \\
2.851\end{array}$ & 10.518 & $\begin{array}{l}0.046 \\
5.415\end{array}$ & -0.049 \\
\hline Germany & 144 & $\begin{array}{l}0.505 \\
1.332\end{array}$ & $\begin{array}{l}0.252 \\
3.132\end{array}$ & 9.303 & $\begin{array}{l}0.065 \\
4.508\end{array}$ & 0.675 \\
\hline U.S. & 153 & $\begin{array}{l}1.267 \\
2.379\end{array}$ & $\begin{array}{l}0.386 \\
5.154\end{array}$ & 8.214 & $\begin{array}{l}0.150 \\
6.252\end{array}$ & 2.062 \\
\hline Belgium & 148 & $\begin{array}{l}0.297 \\
0.569\end{array}$ & $\begin{array}{l}0.310 \\
4.046\end{array}$ & 9.024 & $\begin{array}{l}0.101 \\
6.329\end{array}$ & 0.430 \\
\hline Sweden & 133 & $\begin{array}{l}1.168 \\
2.965\end{array}$ & $\begin{array}{l}0.136 \\
1.567\end{array}$ & 9.991 & $\begin{array}{l}0.018 \\
4.304\end{array}$ & 1.351 \\
\hline Switzerland & 68 & $\begin{array}{l}-0.605 \\
-1.573\end{array}$ & $\begin{array}{l}0.383 \\
3.491\end{array}$ & 5.620 & $\begin{array}{l}0.156 \\
3.100\end{array}$ & -0.980 \\
\hline \multicolumn{7}{|c|}{ Long-term rate } \\
\hline U.S. & 185 & $\begin{array}{l}0.461 \\
0.988\end{array}$ & $\begin{array}{l}0.264 \\
3.735\end{array}$ & 10.429 & $\begin{array}{l}0.071 \\
6.294\end{array}$ & 0.626 \\
\hline France & 184 & $\begin{array}{l}-0.095 \\
-0.175\end{array}$ & $\begin{array}{l}0.206 \\
2.860\end{array}$ & 11.022 & $\begin{array}{l}0.043 \\
7.306\end{array}$ & -0.119 \\
\hline Netherlands & 170 & $\begin{array}{l}0.309 \\
0.714\end{array}$ & $\begin{array}{l}0.158 \\
2.062\end{array}$ & 10.954 & $\begin{array}{l}0.025 \\
5.615\end{array}$ & 0.367 \\
\hline Belgium & 166 & $\begin{array}{l}-0.234 \\
-0.435\end{array}$ & $\begin{array}{l}0.328 \\
4.449\end{array}$ & 9.121 & $\begin{array}{l}0.108 \\
6.901\end{array}$ & -0.348 \\
\hline Germany & 163 & $\begin{array}{l}0.693 \\
1.685\end{array}$ & $\begin{array}{l}0.309 \\
4.301\end{array}$ & 9.622 & $\begin{array}{l}0.103 \\
5.180\end{array}$ & 1.002 \\
\hline Sweden & 114 & $\begin{array}{l}0.116 \\
0.361\end{array}$ & $\begin{array}{l}0.112 \\
1.279\end{array}$ & 10.171 & $\begin{array}{l}0.014 \\
3.411\end{array}$ & 0.131 \\
\hline Canada & 113 & $\begin{array}{l}0.065 \\
0.129\end{array}$ & $\begin{array}{l}0.254 \\
2.774\end{array}$ & 8.133 & $\begin{array}{l}0.065 \\
5.375\end{array}$ & 0.087 \\
\hline Italy & 113 & $\begin{array}{l}0.443 \\
1.377\end{array}$ & $\begin{array}{l}0.059 \\
0.620\end{array}$ & 9.962 & $\begin{array}{l}0.003 \\
3.378\end{array}$ & 0.470 \\
\hline Norway & 113 & $\begin{array}{l}0.243 \\
0.529\end{array}$ & $\begin{array}{l}0.296 \\
3.030\end{array}$ & 0.000 & $\begin{array}{l}0.076 \\
4.832\end{array}$ & 0.345 \\
\hline Switzerland & 68 & $\begin{array}{l}-0.713 \\
-1.729\end{array}$ & $\begin{array}{l}0.304 \\
2.413\end{array}$ & 5.526 & $\begin{array}{l}0.081 \\
3.322\end{array}$ & -1.024 \\
\hline
\end{tabular}

Sources: See appendix.. 
Table 7. Deviations from UIP relative to U.K.

\begin{tabular}{|c|c|c|c|c|c|c|c|}
\hline & France & etherlands & Belgium & U.S. & Germany & Sweden & Switzerland \\
\hline $1800-1815$ & $\begin{array}{r}-0.934 \\
(12.221)\end{array}$ & & & & & & \\
\hline $1816-1860$ & $\begin{array}{r}0.105 \\
(1.860)\end{array}$ & $\begin{array}{r}-0.575 \\
(2.227)\end{array}$ & $\begin{array}{r}0.769 \\
(1.901)\end{array}$ & $\begin{array}{r}5.270 \\
(3.132)\end{array}$ & $\begin{array}{r}1.424 \\
(5.447)\end{array}$ & $\begin{array}{r}1.058 \\
(2.668)\end{array}$ & \\
\hline $1865-1913$ & $\begin{array}{r}-0.350 \\
(1.300)\end{array}$ & $\begin{array}{l}-0.048 \\
(1.071\end{array}$ & $\begin{array}{r}-0.461 \\
(2.762)\end{array}$ & $\begin{array}{r}2.428 \\
(1.455)\end{array}$ & $\begin{array}{r}0.285 \\
(1.276)\end{array}$ & $\begin{array}{r}1.600 \\
(1.508)\end{array}$ & $\begin{array}{r}0.332 \\
(0.420)\end{array}$ \\
\hline 1926-1939 & $\begin{array}{r}-2.224 \\
(17.219)\end{array}$ & $\begin{array}{r}3.166 \\
(11.927)\end{array}$ & $\begin{array}{r}14.598 \\
(44.961)\end{array}$ & $\begin{array}{r}1.531 \\
(16.788)\end{array}$ & $\begin{array}{r}-4.853 \\
(33.263\end{array}$ & $\begin{array}{r}1.690 \\
(4.964)\end{array}$ & $\begin{array}{r}2.404 \\
(14.483)\end{array}$ \\
\hline $1950-1972$ & $\begin{array}{c}-0.211 \\
(7.992)\end{array}$ & $\begin{array}{r}1.074 \\
(4.971)\end{array}$ & $\begin{array}{r}2.188 \\
(4.267)\end{array}$ & $\begin{array}{r}-0.178 \\
(4.567)\end{array}$ & $\begin{array}{r}3.146 \\
(5.856)\end{array}$ & $\begin{array}{r}1.803 \\
(4.167)\end{array}$ & $\begin{array}{r}-0.619 \\
(5.243)\end{array}$ \\
\hline 1973-1999 & $\begin{array}{r}-0.638 \\
(10.568)\end{array}$ & $\begin{array}{r}-0.928 \\
(11.277)\end{array}$ & $\begin{array}{r}0.117 \\
(11.426)\end{array}$ & $\begin{array}{r}-0.424 \\
(13.284)\end{array}$ & $\begin{array}{r}-1.001 \\
(11.759)\end{array}$ & $\begin{array}{r}-1.375 \\
(10.992)\end{array}$ & $\begin{array}{r}-1.915 \\
(12.796)\end{array}$ \\
\hline 1973-1989 & $\begin{array}{r}-0.024 \\
(10.763)\end{array}$ & $\begin{array}{r}0.089 \\
(11.449)\end{array}$ & $\begin{array}{r}1.480 \\
(11.454)\end{array}$ & $\begin{array}{r}-0.888 \\
(15.963)\end{array}$ & $\begin{array}{r}-0.043 \\
(12.397)\end{array}$ & $\begin{array}{r}-1.352 \\
(12.490)\end{array}$ & $\begin{array}{r}-0.597 \\
(12.912)\end{array}$ \\
\hline 1990-1999 & $\begin{array}{r}-1.682 \\
(10.714)\end{array}$ & $\begin{array}{r}-2.659 \\
(11.361)\end{array}$ & $\begin{array}{r}-2.200 \\
(11.597)\end{array}$ & $\begin{array}{r}0.365 \\
(7.462)\end{array}$ & $\begin{array}{r}-2.631 \\
(11.027)\end{array}$ & $\begin{array}{r}-1.413 \\
(8.469)\end{array}$ & $\begin{array}{r}-4.156 \\
(12.952)\end{array}$ \\
\hline Combined & $\begin{array}{r}-0.463 \\
7.841\end{array}$ & $\begin{array}{l}0.090 \\
6.129\end{array}$ & $\begin{array}{l}0.613 \\
6.988\end{array}$ & $\begin{array}{l}1.780 \\
8.004\end{array}$ & $\begin{array}{r}0.214 \\
11.770\end{array}$ & $\begin{array}{l}0.842 \\
5.839\end{array}$ & $\begin{array}{r}-0.354 \\
9.929\end{array}$ \\
\hline
\end{tabular}

Sources: See appendix.

Notes: Standard deviations are in parentheses under the respective means. The combined mean is the mean of the observations within the first six subperiods; the combined standard deviation is computed as the square root of the sum of the sums of squares for the six subperiods divided by the relevant degrees of freedom. 
Table 8. Real stock returns: Subperiod averages of cross-country standard deviations of quinquennially averaged data

\begin{tabular}{ccccccc}
\hline Period & SD2 & SD4 & SD5 & SD6 & SD7 & SD8 \\
\hline $1800-1814$ & 3.03 & & & & & \\
$1815-1849$ & 3.01 & & & & & \\
$1850-1874$ & 3.78 & 3.74 & & & & \\
$1875-1914$ & 2.62 & 3.18 & 3.96 & & & \\
$1915-1924$ & 1.83 & 7.12 & 9.14 & 8.48 & 8.09 & 7.17 \\
$1925-1939$ & 3.36 & 5.83 & 6.01 & 5.88 & 6.67 & 6.33 \\
$1940-1940$ & 0.92 & 7.35 & 7.45 & 7.45 & 18.04 & 16.88 \\
$1950-1974$ & 4.58 & 6.40 & 6.33 & 6.60 & 7.12 & 7.02 \\
$1976-2000$ & 3.04 & 4.86 & 5.36 & 5.34 & 6.25 & 6.17 \\
\hline
\end{tabular}

Sources: See ap pendix.

Notes: The eight countries listed in order of their inclusion are the United Kingdom, the United States, France, Germany, Japan, Denmark, Sweden and Canada. 